\title{
28 Research Square \\ The determinants of the global competitiveness of the economy: a dynamic panel approach applied to the WAEMU country
}

Moussa SIGUE ( $\nabla$ msigue.reche@gmail.com )

Department of Economics and Management, University Ouaga II

Research

Keywords: Global Competitiveness, Determinants, Dynamic Panel, WAEMU

Posted Date: July 7th, 2020

DOl: https://doi.org/10.21203/rs.3.rs-38274/v1

License: (c) (1) This work is licensed under a Creative Commons Attribution 4.0 International License.

Read Full License

Version of Record: A version of this preprint was published at Applied Finance and Accounting on August 5th, 2020. See the published version at https://doi.org/10.11114/afa.v6i2.4964. 


\section{Abstract}

This article examines the determinants of the overall competitiveness of the WAEMU economy from a dynamic panel approach over the period 2011-2017. The estimate by the method of generalized moments in system (GMM) Reveled that the delayed competitiveness of a period financial development, GDP per head, internal absorption and taxes on foreign trade affects positively and significantly the overall competitiveness of the WAEMU countries while economic openness, the rate of inflation and the quality of institutions have contributed negative and significant. It emerges from this work that an improvement in the overall competitiveness of the Union's economy imperatively requires accelerating the process of development of quality, the financial system as well as protecting local industries from external pressure to through a more adequate commercial policy taking into account the constraints linked to commercial agreements.

\section{Introduction}

In a context of economic opening marked by increased competition, the most complex challenge facing most countries is that of making their economies more competitive. This is due to the fact that economic opening is only beneficial for economies which are able to impose themselves both on the domestic and external market. (Verner, 2015). This challenge is particularly important for the member countries of the West African Economic and Monetary Union (WAEMU) which for several decades have suffered from a lack of competitiveness on a regional and international scale (Dumont and Mesple-Somps, 2000).

The notion of competitiveness refers to the ability of an economy to deploy an activity and generate an income, the activity being subject to competition. Two types of competitiveness can be systematically distinguished, which moreover can be related to one another. The first type is based on prices. In this case, the economic entity is able to respond to the competition by adjusting its prices. It is important to clarify that price competitiveness does not account for all the drivers of an economy's competitiveness since it does not explain how an economy can successfully maintain its competitiveness better and longer beyond the price factor. Besides price competitiveness, there is a second type of competitiveness which involves other structural factors such as the adequacy of the products offered to consumers' tastes, the constraint linked to production capacity, innovation, overall productivity, product quality, profitability and investment in public infrastructure. This second category of competitiveness is called structural competitiveness or non-price competitiveness. It indicates the ability of an economic entity to stand out from the competition by means other than price. The structural competitiveness of the economy highlights two fundamental points. The first point highlights the ability to attract activities and the capacity of the economy to face competition and the second points out that a competitive economy makes it possible to provide populations with better living conditions (Scott, 1995).

By considering these two types of competitiveness in a more global approach, it is possible to translate that a globally competitive economy is able to face price competition both on the domestic and foreign market and also to ensuring better living conditions for its populations. 
While the gains linked to international competitiveness seem enormous in the improvement of living conditions, the WAEMU countries have the poorest populations in the world, and present inglorious situations in terms of international competitiveness. On this subject, over the period 2000-2018, the average GDP per capita of the Zone increased by $1.47 \%$ against $2.6 \%$ for Africa South of the Sahara (SSA), 3.66\% for the zone Euro, 3.89\% for Latin America and the Caribbean and 5.48\% for East Asia and the Pacific (World Bank, 2020). Regarding the Global Competitiveness Index (GCI), it was on average 3.57 in the WAEMU over the period 2011 - 2015 against 3.58 for Sub - Saharan Africa, 3.87 for North Africa, 3.97 for Latin America and the Caribbean 4.29 for Southeast Asia and 4.45 for BRICS countries (FEM, 2015). From these comparisons, it is clear that WAEMU remains the Zone less competitive during this period and consequently, one whose populations had the lowest incomes per capita. This position was maintained since 2019, according to Mehouachi (2019), no WAEMU country is ranked in the top 50 of the most competitive countries in the world.

In this context of low competitiveness, it is important to know the determinants of the overall competitiveness of the WAEMU economy. The objective of the article is to identify the determinants of the global competitiveness of the WAEMU economy, starting from a dynamic panel approach. To do this, it analyzes all aspects of competitiveness through the $\mathrm{GCl}$ composite indicator. $\mathrm{GCl}$ presented to the rest of the article, are $t$ an indicator allows as to take into account more factors relating to business performance, other important factors such as the quality of institutions and the standard of living of population. The choice of the dynamic approach is guided by the assumption that competitiveness is not inherited but built over time. Consequently, the competitiveness recorded in the previous period has an effect on the level of competitiveness in the following period.

\section{Literature Review}

\subsection{Theoretical review}

In the economic literature, the concept of competitiveness is frequently used in the context of economic performance analyzes. Although several studies analyze it empirically or discuss its merits from the point of view of improving the living conditions of populations, it must be recognized that there is no consensus on its definition or on the precise methods to be used to measure it. In the theoretical literature, two types of competitiveness are distinguished, namely price competitiveness and non-price competitiveness also qualified as structural competitiveness.

The price concept refers to the productive capacity of the company, that is to say, its ability to have high productivity with low production costs. For Porter (1990), it is more optimal to study competitiveness in the microeconomic sense rather than the national level. It should also be noted that price competitiveness is the component of competitiveness most frequently analyzed in the economic literature. Thus, it reflects the ability of the national economy to compete by offering lower prices than those of its competitors. According to Rousse (1992), this approach to competitiveness is important because it makes it possible in particular to apprehend the effects of changes in price and the exchange rate, but it does not take into 
account all the drivers of the potential competitiveness of an economy. Price competitiveness, despite its fairly simple statistical measurement, does not explain how an economy can successfully maintain its competitiveness better and longer beyond the price factor.

The main criticism brought to the analysis of a nation's competitiveness by showing prices concerns its interpretation. Indeed, there often appears a complexity in the interpretation of price competitiveness. When it deteriorates, it could translate into higher production costs or an improvement in the quality of exported products. But by making the Egyptohèse that the rise in prices is dependent on an improvement in the quality of the exported products, that is favorable to a reinforcement of the structural competitiveness since the exports are of better qualities.). On this subject, Krugman (1988) maintains that there is a real difference between competitiveness in the sense of an enterprise and that measured on the scale of a country because the competitiveness of a nation is not simply determined. By the ability to sell more, but above all by its ability to record a gain in overall productivity of the economy.

Faced with the criticisms that have been made in relation to the analysis of price competitiveness, the proponents of non-price competitiveness have advocated the analysis of structural competitiveness which, in turn, involves other structural factors such as product adequacy offered to consumer tastes, the constraint linked to production capacity, level of industrialization, innovation, product quality, profitability, spending on public infrastructure as well as all other endogenous factors likely to improve the competitive position of an economy both on the domestic and external market, the purpose of which is to improve the living conditions of populations. In order to take into account all aspects of competitiveness, the World Bank has proposed to analyze the competitiveness of nations in its global component using an indicator known as the Global Competitiveness Index (ICG). Global competitiveness takes into account all the drivers of competitiveness (price and structural).

\subsection{Empirical debates}

In the empirical literature, debates on the concept of competitiveness have crystallized around its measurement indicators as well as its determinants.

Indeed, we had to wait for the work of Aschauer (1989a and 1989b) to watch a replay of the contribution of spending public economic performance. The author thus estimated a production function extended to public capital to highlight the specific contribution of public infrastructure to improving the overall competitiveness of the economy. His work has laid the groundwork for an explosion of new endogenous growth models that now see investment in public infrastructure as a self-sustaining gain factor in productivity and long-term competitiveness. Among these developments, the reference work is that of Barro (1990). Its model highlights the role of public infrastructure in general and transport infrastructure in particular in the competitiveness of the economy. In this chain, it emerged that the transport infrastructures intervene as well in the sphere of production as in that of marketing. When infrastructure is poor or ineffective, this results in higher direct transport costs and longer delivery times, which significantly increases trade costs and therefore reduces competitiveness. Consequently, an improvement 
in public spending on infrastructure contributes to reducing transport costs and therefore contributes to improving the volume of trade in the country (Limao and Venables, 1999).

On the same trajectory analysis, Kopp (2007), reached the conclusion that the road infrastructure may have positive effects on macroeconomic productivity of nations. The author's analysis covered thirteen (13) Western European countries. The fixed effects estimate of the contribution of the national road networks gives a significant coefficient of 0.71 . He explains that the countries in which companies are large consumers of road transport services are more likely to benefit from investment in transport infrastructure.

In general, studies that have examined the contribution of public infrastructure spending in general to the competitiveness of the economy have succeeded in establishing a positive impact of these on overall productivity of the economy. The synthesis of work shows that over a long period, the elasticities are between 0.23 and 0.71 (Munnelle, 1990a ; Eeisner, 1991 ; Ford and Poret, 1991).

In another, Camagni (2002) discusses how more depth of two subordinates aspects of the concept of competitiveness. Thus, he first attaches himself to the very notion of territorial competitiveness in order to test its theoretical solidity. The concept of competitiveness, considered at the national level, was indeed strongly criticized by Krugman (1994), causing in particular the perplexity of the regional economists. However, explains Camagni (2002), the foundations of these criticisms have never been examined systematically for more limited entities. Briefly, passing on to other developments, we note that for Krugman (1994), and economists do not dispute it on this point, the efficiency of sectors not exposed to international competition represents an essential element for the prosperity of a nation, more than competitiveness in foreign markets. However, it appears that the merits of this argument must be closely related to the size of the country (region) considered and its openness to trade. Depending on the circumstances, the two notions of internal productivity and external competitiveness may thus appear much more similar.

The role of the institutional environment in the competitiveness of a nation has also been studied. In this regard, Ulman (2013) uses Pearson's correlation test and simple regression to determine and analyze the nature of the relationship between competitiveness and corruption. Using global competitiveness indicators, he finds that corruption significantly influences competitiveness. He analyzed the relationship between these variables by considering the level of development of the countries. He finds a strong negative relationship between competitiveness and corruption in developed countries. This relationship remains in developing countries but it is very weak compared to developed countries; while it is even twodimensional in middle-income countries.

Lafay (1995) focused on the competitiveness of the European economy and explained how the high costs of raw materials have led to the decline of European competitiveness. For him, it is not the implementation of the single market that has most hampered European competitiveness in recent decades but rather the high cost of raw materials which is closely linked to the cost of transport. The author tells us that the high cost of e transportation greatly affects the production cost of enterprises 
which in turn negatively affects competitiveness. As for Mody and Reinfeld (1995), its have been more specific when they analyzed the factors determining the competitiveness of Hong Kong economies, Singapore and Taiwan with a set of factors of cost indicators and environmental quality. With the main objective of analyzing the contribution of infrastructure to the competitiveness of the economies of these areas, the authors came to the conclusion that an improvement in investment in public infrastructure and in the quality of the environment, produces a reduction in supply costs, lower delivery times, accelerate production cycles and increase competitiveness.

In SSA, the economic literature on the determinants of competitiveness remains fairly limited and most of the existing studies have been limited to the evaluation of the effects of certain economic factors such as the exchange rate, the fixity of the F.CFA and the transport infrastructure on the price competitiveness of nations.

Indeed, Bogetic et al. (2007) worked on the Ivory Coast case, noting that the overvaluation of the F.CFA had negative effects on the competitiveness of Ivorian agriculture. Outside the CFA zone, competitiveness has also been studied in some SSA countries. In this regard, Adeoti (2005), for instance, highlighted the positive role of information technology in the competitiveness of the manufacturing industry in Nigeria. As regards the role of public infrastructure in the competitiveness of economic, Dumont and Mesplesomps (2000) analyzed the extent to which an increase in public infrastructure, including road infrastructure allows for better business performance of the Senegalese economy and that of its competitiveness. In their conclusions, the authors established that a policy of expanding public infrastructure in general has direct effects on domestic prices and the wage rate and therefore on the commercial performance of the country's economy. This conclusion shows how the poor quality of transport infrastructure in general affects the efficiency of production, domestic prices and wages in lowincome countries.

In another register, the analyzes of Agbor and Taiwo (2014) explored the effects of road infrastructure on the competitiveness of economies. They worked on the fundamental determinants of the competitiveness of SSA countries with the specific case of the WAEMU zone and the Economic and Monetary Community of Central Africa (CAEMC) zone. The analysis made using panel data compared the level of competitiveness of the two areas. Based on their analysis, the authors were able to establish a positive correlation between investments in road infrastructure and international competitiveness in the two areas.

\section{Analysis Methodology \\ 3.1. Empirical model}

In analyzing the compétitivit é economic model that is often used is that of Porter (1990). In his model, four groups of factors influence the competitiveness of the economy. The first refers to the allocation of the country in infrastructure publics, in skilled labor as well as all the other factors likely to improve economic productivity. The second concerns demand conditions and specifies how the nature of the local market for goods and services is decisive for the competitiveness of a nation. The third factor emphasizes the absence or presence in the 
country of internationally competitive suppliers or other complementary industries. The fourth element relates to the strategy of firms, their structures and the rivalry they face.

However, in Porter's (1990) approach, these variables are considered to be exogenous. Thus, the empirical model retained in this article is that of Kopp (2007) which is an extension of the model of Barro (1990). This model is part of endogenous growth by considering public spending as a self-sustaining gain factor in the productivity of private factors and in the overall productivity of the economy. The choice of this model is guided by the fact that Kopp (2007), assessing the impact of spending on infrastructures public on competitive, derived an equation overall productivity gain. However, Krugman (1994) had already ruled that overall productivity is an indicator of the overall competitiveness of the economy in the medium and long term.

With regard to the choice of the dynamic panel, it is essentially determined by the fact that past competitiveness could have positive effects on future competitiveness. As Porter (1990) admitted, competitiveness is not inherited but built over time. Thus, taking into account all these aspects, the empirical dynamic panel model that is used in this article takes the following form :

$$
I C G_{i t}=\alpha+\delta I C G_{i t-1} \beta X_{i t}+\varepsilon_{i t}
$$

In equation (1) $I C G_{i t}$ is competitive overall country $i$ at time $t, I C G_{i t-1}$ is the competitiveness of the country $i$ at the time $\mathrm{t}-1, X_{i t}$ represents a vector of explanatory variables and $\varepsilon_{i t}$ is the error term of the country $i$ to the date $t$.

\subsection{Estimation method}

For the estimation of the model, we use the Generalized Moments Method (GMM) to identify the determinants of the overall competitiveness of the WAEMU. The choice of this method is linked to the fact that the number of individuals in the model exceeds that of the period. This method provides solutions to problems of simultaneity bias and controls the specific effects. In addition, it solves the endogeneity problem of one or more explanatory variables, in particular the presence of the lagged dependent variable.

There are, however, two variants of the GMM estimator. The first is the first difference estimator of Arellano and Bond (1991) which consists in taking for each period the first difference in the equation to estimate and eliminating the individual effects and then in instrumenting the explanatory variables of the equation in first difference by their values in level delayed by one or more periods. The second version is the system estimator of Blundell and Bond (1998). This estimator is an improved version of the first. The system estimator of Blundell and Bond (1998). This method consists in making a combination of the first difference equation with the level equations in which the variables are instrumented by their first differences. Therefore, the GMM in the system is more efficient than the GMM in the first difference.

Thus, in the estimation of our model, we use GMM as a one-step system in order to be able to take advantage of the advantages it offers, notably the absence of concurrency and autocorrelation bias. Before proceeding to the estimation, we carry out tests in order to provide the efficiency of our results. Thus, we perform the preliminary model specification tests, the unit root test, the global significance test, the Sargan / Hansen overidentification test, and the Arellano and Bond error autocorrelation test.

\section{Variables And Data Source}

\subsection{Variable explained : global competitiveness indicator}

Several indicators are used by economists to measure the competitiveness of the economy. However, it should be noted that each indicator is established according to the focus of the study. In general, each indicator used to assess the competitiveness of the economy depends on the facts highlighted in the definition of the concept. In this regard, Sigue (2018) states that each type of indicator is valid only for a particular aspect of the analysis. In the literature, several indicators including the real effective exchange 
rate, the weighted export and import index, the net export index proposed by Latruffe (2010) and the overall productivity of Krugman (1994) can be used to capture the level of competitiveness of nations.

Regarding the real effective exchange rate, authors like Mulder et al. (2004) and Ball et al. (2006) and Bceao (2013) recommended its use in the case of countries with different currencies. This indicator is not used in this article because it only reflects the price aspects of competitiveness. Also, in the WAEMU space, the currency is common to the member countries.

As for the weighted export and import index, it is proposed by the OECD. In the measurement of the international economic competitiveness of France, Durand et al. (1987) started from import and export competitiveness to establish the overall competitiveness index. An analysis of this indicator shows that it is based solely on import and export prices. Presumably, it would be more optimal to use it to measure price competitiveness which only reflects one aspect of overall competitiveness.

As for Latruffe's export index (2010), it is limited to measuring external trade performance which is a result of overall competitiveness. However, the relationship between commercial performance and competitiveness is not reflective. Otherwise, a competitive economy is a successful economy, but a successful economy is not necessarily competitive. Therefore, this indicator does not instantly explain the overall competitiveness measured in this article.

On overall productivity, Krugman (1994) bases his argument by stating that what matters most is overall productivity because it determines the real per capita income in the medium and long term of a national economy. As a result, overall productivity is a good indicator of economic competitiveness. It is always tempting to assume that the ability to export a good is determined by the presence of an absolute productivity advantage. The higher the productivity, the more competitive this economy is. The major problem of measuring the global competitiveness of African countries by overall productivity is linked to the unavailability and low quality of data. Therefore, this indicator is not used in this article.

In this article, the World Bank $\mathrm{GCl}$ is used. This indicator identifies the drivers of overall productivity necessary for sustained and sustainable economic growth. The $\mathrm{GCl}$ is structured around twelve (12) pillars, namely institutions, infrastructure, macroeconomic environment, health and primary education, higher education and training, efficient product markets, labor market efficiency, financial market development, technological development, market size, business sophistication and innovation. In order to be able to take into account the level of development of the countries, the twelve (12) pillars of competitiveness are classified in three classes. The first class with the first three pillars is that of basic parameters; the second class which groups together the following six pillars is that of sources of efficiency and the third class which groups together the last two pillars is that of sources of innovation and sophistication.

The World Bank determines the $\mathrm{GCl}$ by giving weights to the different pillars to take into account the level of development of each country. The calculation is based on successive aggregations of scores starting from the indicators until reaching the $\mathrm{GCl}$ score $(\mathrm{FEM}, 2015)$. The value of the $\mathrm{GCl}$ is between 1 and 7 
where the lowest level of competitiveness indicates and 7 the highest level. It is a comprehensive indicator of competitiveness in the sense that it takes into account all sectors and the well-being of the population.

\subsection{Explanatory variables}

In the economic literature, several variables are likely to affect the overall competitiveness of the economy. The most used in the analyzes are the following:

GDP per capita (GDPH) : This is a variable that reflects the level of economic development in the country. Its growth is synonymous with the national economy ensuring an efficient sphere of production and marketing. The expected sign is positive.

Inflation (INFL) : The effect of inflation is a controversial issue. Some studies claim that inflation has a positive impact on growth ( Dornbusch et al., 1996 ), while other studies suggest that this effect is characterized by a non-linear relationship ( Fischer, 1993; Kremer et al., 2009). The expected sign is ambiguous. The expected sign is ambiguous.

Tax on foreign trade (WSBI) : It represents all the tax levied by the E State on foreign trade. In general, taxation is made on imported products. Thus, its increase leads to a decrease in imports of UEMOA from the rest of the world since the products become more expensive. The expected sign is positive.

Economic openness (OUEC) : it captures the intensity of commercial interactions with the rest of the world. The sum ratio of exports and imports to GDP is used to measure it. Its sign is ambiguous because if exports can act positively on competitiveness, imports are on the other hand can have negative effects.

Financial Development (DEFI) : It is important to emphasize that several indicators are used in the literature to measure financial development. These indicators can be grouped into two categories. Firstly, there are the indicators relating to the size and efficiency of banking activity and secondly, there are the indicators relating to the functioning of the financial markets. Due to the low level of development of the financial market in developing countries in general, it is more advisable to use the first category. Like King and Levine (1993), credit to the private sector as a percentage of (GDP) is used as an indicator of financial development in this work. In addition to these variables, a set of control variables, frequently used in the analysis of economic performance, is included in the estimates.

Ratio of foreign direct investment (RIDE) : It is obtained by comparing foreign direct investment to GDP. This variable captures the pressure of internal demand on exports. When it is high, this translates into high absorption, which assures companies of economies of scale. According to Henry (1994), the macroeconomic analysis considers that there is a complementary relationship between export and the foreign investment ratio. Therefore, the expected sign is therefore positive.

Internal absorption (ABIN) : it represents the ratio between domestic demand and GDP. It captures the pressure of internal demand. Strong absorption is in principle a sign of the existence of a potential 
market and should allow companies to achieve economies of scale. The expected sign is therefore positive.

Quality of institutions (QUIN) : it is captured by the average of the six indicators of Kaufmann, et al. (2010). These six indicators are citizen responsibility, political stability and freedom from violence, government efficiency, regulatory quality, the rule of law and the control of corruption. Our indicator is measured on a scale of -2.5 to 2.5 where the highest value translates into a better quality of the institutions. Good institutions are likely to generate a more competitive economy from which a positive sign is heard.

\subsection{Source of data}

The data used in this article are annual and come exclusively from the World Bank database except the $\mathrm{GCl}$ obtained from the GEF and the quality of the institutions coming from the World Governance Indicator (WGI) database. The data cover the period from 2011 to 2017, i.e. seven (07) years. The choice of this period essentially guided by the availability of data on the explained variables $(\mathrm{GCl})$.

\section{Result And Discussion 5.1. Descriptive analysis of data}

Table 1 presents the descriptive characteristics of the data making up the analysis sample. 
Table 1

statistics of the economic variables in the sample from 2011 to 2017.

\begin{tabular}{|c|c|c|c|c|c|c|c|c|}
\hline Variable & BEN & BFA & CIV & GNB & PWM & NGR & SEN & TOG \\
\hline $\mathrm{GCl}$ & 3.51 & 3.25 & 3.82 & 3.13 & 3.78 & 2.36 & 3.72 & 3.4 \\
\hline $\begin{array}{l}\text { Financial } \\
\text { development }\end{array}$ & 23.26 & 30.05 & 24.61 & 9.56 & 25.78 & 15.54 & 28.19 & 40.19 \\
\hline $\begin{array}{l}\text { GDP for the } \\
\text { habitant }\end{array}$ & 843.19 & 665.03 & 1539.25 & 594.63 & 746.24 & 389.98 & 1434.30 & 646.52 \\
\hline Inflation & -0.16 & 0.35 & 0.88 & 1.44 & 0.47 & 1.29 & 0.76 & 0.96 \\
\hline $\begin{array}{l}\text { Degree of } \\
\text { openness }\end{array}$ & 62.48 & 65.10 & 66.82 & 59.48 & 61.82 & 52.47 & 56.54 & 86.39 \\
\hline IMCE & 11.9 & 16.2 & 8.8 & 15.1 & 10.1 & 21.33 & 16.93 & 10.7 \\
\hline RIDE & 1.11 & 1.94 & 0.19 & 1.38 & 2.76 & 5.16 & 2.52 & 2.32 \\
\hline Absorption & 0.89 & 0.78 & 0.19 & 0.73 & 0.39 & 0.72 & 1.29 & 0.91 \\
\hline $\begin{array}{l}\text { Quality of } \\
\text { institutions }\end{array}$ & -0.31 & -0.40 & -0.58 & -1.17 & -0.81 & -0.69 & -0.08 & -0.73 \\
\hline
\end{tabular}

Source : calculations of the author from World Bank (2020) and FEM (2017) data.

The observation in Table 1 generally highlights a quasi-homogeneity according to the countries of the economic and financial aggregates according to the countries over the period 2011-2017. This low variability, however, masks some peaks irregularitys. In terms of per capita income, the Ivory Coast $(1,539.25$ USD) and Senegal (1,434.30 USD) are doing better with income than the rest of the countries of the Union. Regarding financial development, only Guinea Bissau stands out, the rest of the countries have a homogeneous level. One point that should be emphasized is the general weakness of the quality of the institutions of the EMEA countries. This could be related to political instability, problems soci o-policies and the level high of corruption of years these countries. Regarding the competitiveness overall, it is low fa ç general is in the Union. Its comments more informations feels probably a behavior very irregular for the economy of the Union. For example, low absorption and high degree of openness attest to the strong dependence of the UEMOA economy to external factors, naturals (climate) and those within the context of the global economy.

\subsection{Estimation result}

Before presenting the results of the estimation of the determinants of the overall competitiveness of the WAEMU economy, we first present the results of the basic tests. 
The result of the model specification test gave a fisher statistic of $F(12,86)=4.97$ and $P$-value $=F=$ 0.0003 . At the $5 \%$ threshold, this empirical evidence makes it possible to reject the null hypothesis of the absence of individual effects. Then, there is homogeneity of the coefficients of the model and this translates that the data support the selected panel structure. In addition, Pesaran's (2004) interindividual dependence test concluded that autocorrelation was present at the $1 \%$ threshold. This result made it possible to carry out the stationarity test of the series using the second generation test of Pesaran (2007).

Table 2 presents the results of the stationarity test.

Table 2

tests of unit root in panel on variables

\begin{tabular}{|llll|}
\hline Variables & CPIS * & Differentiation Level & Decision \\
\hline GCI & $-1,657$ & 0 & Stationary at $5 \%$ \\
\hline CHALLENGE & -2.459 & 0 & Stationary at $1 \%$ \\
\hline GDPH & -2.605 & 0 & Stationary at $5 \%$ \\
\hline INFL & 1,700 & 1 & Stationary at $5 \%$ \\
\hline OUEC & -2.865 & 0 & Stationary at $5 \%$ \\
\hline IMCE & -0.696 & 0 & Stationary at $5 \%$ \\
\hline WRINKLED & 1,700 & 1 & Stationary at $5 \%$ \\
\hline ABIN & -2.971 & 0 & Stationary at $5 \%$ \\
\hline QUIN & 1,700 & 1 & Stationary at $5 \%$ \\
\hline Source : author's calculation from World Bank (2020) and GEF (2017) data. \\
\hline
\end{tabular}

It is apparent from Table 4 that the ' index of global competitiveness, on financial development, the per capita GDP, the economic opening, the tax on foreign trade and the domestic absorption are stationary in level while the inflations variables foreign direct investment ratio and quality of institutions are stationary in primary difference.

\section{Efficiency of the GMM estimator in dynamic panel}

First, the instrument used in our regression is valid because the Sargan test and the Hansen test did not reject the hypothesis of validity of the lagged variable of employment in level as an instrument. In addition, there is no first and second order autocorrelation of first difference errors because the first AR (1) and second order AR (2) autocorrelation test of Arellano and Bond validated assumption of no autocorrelation of errors. The tests Sargan Hansen and lead to the conclusion that the $5 \%$ we do not reject the null hypothesis of on identifying patterns. Thus, it is possible to conclude that the models are very dynamic. For the sake of eliminating the presence of heteroskedasticity, we estimate the model by 
the GMM method in a one-step system using the robust option, since it makes it possible to correct the students statistics of heteroskedasticity. Therefore, we can conclude that all of our results are robust.

Table 3

The determinants of the global competitiveness of the economy of the WAEMU

\begin{tabular}{|c|c|c|c|}
\hline Variables & coe cients & Standard deviations & t - student \\
\hline Delayed competitiveness & $0.0095048 * \star \star$ & 0.002429 & 3.91 \\
\hline CHALLENGE & 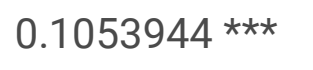 & 0.0057794 & 18.24 \\
\hline GDPH & $0.3095229 * \star \star$ & 0.0185889 & 16.65 \\
\hline OUEC & $-0.0150625 * \star$ & 0.0068622 & -2.20 \\
\hline RIDE & 0.0034994 & 0.0030729 & 1.14 \\
\hline ABIN & 0.0021879 * & 0.0010671 & 2.05 \\
\hline IMCE & 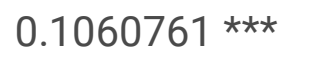 & 0.0275522 & 3.85 \\
\hline INFL & 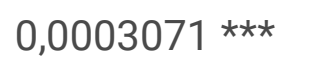 & 0.0000583 & 5.26 \\
\hline QUIN & -0.0829298 * & 0.0384329 & -2.16 \\
\hline Constant & 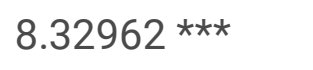 & 1.119172 & 7.44 \\
\hline AR (1) & -1.37 & \multicolumn{2}{|c|}{ Prob $>$ chie $2=0.172$} \\
\hline AR (2) & -1.83 & \multicolumn{2}{|c|}{ Prob > chie2 = 1.098} \\
\hline Sargan test & 12.54 & \multicolumn{2}{|c|}{ Prob $>$ chie $2=0.324$} \\
\hline Number of observations & \multicolumn{3}{|l|}{44} \\
\hline $\begin{array}{l}\text { Note: All variables are in I } \\
\text { hypothesis; the AR (1) and } \\
\text { autocorrelation of order } 1\end{array}$ & 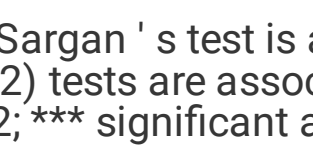 & $\begin{array}{l}\text { ociated with the null p } \\
\text { ed with the hypothesis } \\
\text { \%; ** significant at } 5 \% \text {; }\end{array}$ & $\begin{array}{l}\text { le of instrument } \\
\text { bsence of } \\
\text { ynificant at } 10 \% .\end{array}$ \\
\hline
\end{tabular}

Source : author's calculation from World Bank (2020) and FEM (2017) data.

As can be seen, the results are generally satisfactory. Indeed, in the UEMOA, delayed competitiveness of a period, the development financier, the GDP per capita, domestic absorption and tax trade outside affects positively and significantly the competitiveness overall in the countries of WAEMU while economic openness, the rate of inflation and the quality of institutions contribute negatively and significantly to its formation.

The positive effect of the previous level of competitiveness is by no means counterintuitive because one could expect that a more competitive economy would be able to attract more investment, more productivity and therefore more competitiveness. The competitiveness is in itself a sign of vitality of an economy and therefore a more competitive economy is to guarantee a return on that investment less 
competitive economy. This result is similar to the conclusion of Herciu (2013). For this author, an « initial endowment solid » in competitiveness allows savings generate of resources to ensure the financing of growth later.

With regard to financial development, it has a statistically significant positive effect on overall competitiveness. This result consistent with our expectations, could expliquence by the fact that changes in the financial system would be a channel of mobilization are resources for more profitable investments and stimulating technological innovation by identifying and the financing of development projects with the best returns and long lifespans. This result corroborates the finding of Ibrahim and Alagidede (2018) and Sigue and Barry (2020) which recognized the importance of developing financial economic performance of Africa south of the Sahara (SSA) and the WAEMU. For the latest authors, financial development positively and significantly influences the external performance of the WAEMU countries, especially in the long term. The authors establish that in the short term there is heterogeneity between countries in the effect of financial development on the external performance of different countries. They explain that in developing countries in general and in the WAEMU space in particular, the imperfection of the financial markets reduces the interactions between savings and investment and, by consequence, the external performance of the economies of the Union.

Concerning the GDP per capita, its significance translates that an improvement of the living conditions of the populations is a capital factor of a positive dynamics of the global competitiveness of the economy as well on the domestic market as abroad. Thus, an improvement in per capita income constitutes a source of economic prosperity through the principle of effective demand. According to Yerbanga (2017), the significance of per capita income in explaining the overall performance of the economy would translate the existence of opportunities for economic agents on the regional market.

Regarding economic opening, beyond its econometric significance, economically admits a negative effect on the overall competitiveness of the WAEMU economy. This result contrary to our expectations, reflected a strong open economies of the Union to international market would be a hindrance to the improvement of its competitiveness. This state of affairs could be explained by the fact that the opening up of the economies of the Union exposes national companies to fairly stiff competition led by multinational firms more armed than them. From this fact, they do not come to enjoy the local market to reach maturity phase and disappear soon enough. This point of view is supported theoretically by the infant industries argument put forward by List (1904) to justify the need to protect economies at some stage of their development. This result confirms those of the work of Agbor and Taiwo (2014) who also find this negative effect of openness to international trade on the competitiveness of the countries of the franc zone.

The tax on foreign trade applied by the WAEMU countries has a positive and significant effect on their overall competitiveness. This result is explained by the fact that the tax on foreign trade is an instrument of commercial policy. Therefore, to reduce the impact of competition in domestic markets, the countries could impose taxes on certain imported products. The objective being to encourage and assure the 
domestic production which will be used for export. Such a policy ensures the « survival » of local industries. In principle, membership to the Unions Economic and ratification of certain trade agreements International forced the countries apply common taxation and negotiated multilaterally but however, specific measures referred to as contingency measures may be applied by the countries members the Union.

Regarding inflation, the results of the estimate show that it positively and significantly affects the overall competitiveness of the WAEMU economy. While we expected a negative effect of inflation on competitiveness, the results reveal rather a counterintuitive sign. The explanation for this result is based on the problem of the optimal level of inflation that can be tolerated in an economy. On this subject, was most famous controversy about inflation is that relating to the relevance of the Phillips curve, which suggests the possibility of getting an extra economic growth to lead to a decline in unemployment in return for relatively high inflation. This question has often divided the research community. Indeed, while some are in favor of low inflation, others believe that moderate inflation is likely to positively influence the performance of the economy. In particular, Khan and Senhadji (2000) believe that an inflation level of around 11 to $12 \%$ would not be detrimental to developing economies. In Africa in particular, Combey and Nubukpo (2010) estimate the optimal rate of inflation for UEMOA countries at $8 \%$, one of the convergence criteria of which is the obligation for member states to maintain their levels of inflation below $3 \%$. Thus, the positive effect of inflation on the competitiveness obtained would be justified by the fact that inflation is below the optimal threshold at which its perverse effect on the economy will begin to be felt.

Another significant variable is the quality of the institutions. Indeed, our estimate revealed that the quality of institutions is a limiting factor competitivity overall economies of the WAEMU. The sign obtained is negative and statistically significant. This result is identical to that obtained by Agbor and Taiwo (2014). It makes it possible to say that the WAEMU countries must speed up the process of improving their institutions in order to improve their level of competitiveness. This is all the more important because quality institutes allow all development factors to fully play their scores. At this, Yahyaoui and Rahmani (2009) have shown by example that there is a relationship between financial development, the quality of institutions and the economic growth. For them, a system as financial presupposes a sound institutional framework outlined by a low level of corruption, a more efficient judicial system, and better bureaucracy. As a result, it is possible to emphasize the idea that good governance presents itself as a determinant of financial development.

The results of the estimates also reveal a significance of the internal absorption at the threshold of $10 \%$. This result shows that the Union has a potential market allowing local businesses to achieve economies of scale. However, the low significance could translate that on their own's markets households, the countries of the WAEMU still unable to win and this is partly dependent on foreign competition imposed on them.

One result which appears to be attractive is the insignificance of the foreign direct investment ratio. Indeed, the coefficient of the ratio of foreign direct investments is low and not significant. This situation 
could be explained by the location of foreign direct investment (FDI). Indeed, FDI is mainly oriented towards the mineral and petroleum sectors which are most often transported to industrialized countries for processing.

\section{Conclusion}

In this work, it was a question of identifying the main determinants of the global competitiveness of the WAEMU economy from a dynamic panel approach. We have shown through the existing theoretical literature that the concept of competitiveness has been the subject of several studies although there is it no consensus on its definition or on the specific methods to be used to measure it. Thus, two types of competitiveness are distinguished, namely price competitiveness and non-price competitiveness. In this article, it was a question of taking into account these two types of competitiveness through an indicator of global competitiveness.

After carrying out a GMM estimation in the system, we came to the conclusion that the delayed competitiveness of a period, the financial development, the GDP per capita, the internal absorption and the tax on the foreign trade affect positively and significantly the overall competitiveness of WAEMU countries while economic openness, the rate of inflation and the quality of institutions have a negative and significant contribution.

These results lead to clear economic policy implications. The United States members must necessarily accelerate the process of developing the quality of the institutions to take advantage of all the benefits of the financial system. The countries of the Union must also ensure the protection of local industries from external pressure through a more adequate trade policy taking into account the constraints linked to trade agreements.

\section{Declarations}

*Ethics approval and consent to participate

* Consent for publication

* Availability of data and material «Not applicable»

* Competing interests

* Funding « Not applicable»

* Authors' contributions

* Acknowledgements « Not applicable » 


\section{References}

Adeoti , J. A. (2005). Information technology and competitiveness in a late industrialiser: The case of Nigeria. NORD SÜD Aktuel.

Agbor, A. J., \& Taiwo, O. (2014). The Fundamental Determinants of International Competitiveness in African Countries with Special Reference to the CFA Franc Zone. Economic Research Southern Africa (ERSA).

Arellano , M., \& Bond , S. (1991). Some Tests of Specification for Panel Data : Monte Carlo Evidence and an Application to Employment Equations. Review of Economic Studies, 277-297.

Aschauer , D. (2000). Do states optimize? Public capital and economic growth. The Annals of Regional Science, 34(3), 343-363.

Aschauer, D. A. (1989a). Is Public Expenditure Productive? Journal of Monetary Economics, 23.

Aschauer, D. A. (1989b). Public Investment and Productivity Growth in the Group of Seven. Economic Perspectives, 17-25.

Ball, E., Butault, J. P., San Juan Mesonda, C., \& Mora, R. (2006). Productivity and International Competitiveness of European Union and United States Agriculture. US and EU Perspectives.

Barro , R. (1974). Are Government Bonds Net Wealth? . Journal of Political Economic, 1095-1117.

Barro, R. J. (1990). Gouvernment Spending in a Simple Model of Endogenous Growth. Journal of Political Economy, 125-130.

Bceao. (2013). Rapport sur la compétitivité des économies de I'UEMOA en 2012. BCEAO.

Blundell, R., \& Bond, S. (1998). Initial conditions and moment restrictions in dynamic panel data models 87(1), 115-143. Journal of Econometrics, 87(1), 115-143.

Bogetic, Z., Espina, C., \& Noer, J. (2007). Cote d'Ivoire: Competitiveness, Cocoa and the Real Exchange Rate. The WorldBank.

Camagni , R. (2002). Compétitivité territoriale, milieux locaux et apprentissage collectif: une contre réfléxion critique. Revue d'Economie Regionale et Urbaine, 553-578. Récupéré sur https:doi.org/10391/recu.024.0553

Combey, A., \& Nubukpo, K. (2010). Nonlinear Effects of Inflation on Growth in the WAEMU. ResearchGate, 1-24. Récupéré sur https://www.researchgate.net/publication/46444919

Dejardin, M. (2006). Compétitivité structurelle. Reflets et perspectives de la vie économique, 1-10. doi:DOl: $10.3917 /$ rpve.451.05 
Dornbusch , R., Fischer , S., \& Kearney, C. (1996). Macroeconomics. . Sydney: The Mc-Graw-Hill Companies, Inc.

Dumont, J. C., \& Mesple-Somps, S. (2000). L'impact des infrastructures publiques sur la compétitivité et la croissance: Une analyse en EGC appliquée au Sénégal. Développement Insertion Internationale (DIAL).

Durand, M., \& Giorno, C. (1987). Les indicateurs de compétitivité internationale: aspects conceptuels et évaluation. OCDE.

Eeisner, R. (1991). Infrastructure and Regional Economic Performance : Comment. New England Economic Review, 47-58.

FEM. (2015). Rapport sur la compétitivité en Afrique 2015. Banque Mondiale.

FEM. (2017). Rapport sur la compétitivité en Afrique 2017. Banque Mondiale.

Fischer, S. (1993). The Role of Macroeconomic Factors in Growth. Journal of Monetary Economics, 32, 485-512.

Ford, R., \& Poret, P. (1991). Infrastructure and Private Sector Productivity. OECD, 1-28.

Henry , J. (1994). Investissement direct et exportation existe-t-il un lien? Bulletin de la banque de France, 85-97.

Herciu, M. (2013). Measuring International Competitiveness of Romania by Using Porter's Diamond and Revealed Comparative Advantage. Procedia Economics and Finance(6), 273 -279.

Ibrahim, M., \& Alagidede, P. (2018). Effect of Financial Development on Economic Growth in sub-Saharan Africa. Journal of Policy Modeling. doi:10.1016/j.jpolmod.2018.08.001

Kaufmann, D., Kraay, A., \& Mastruzzi, M. (2010). The Worldwide Governance Indicators : A Summary of Methodology, Data and Analytical Issues. World Bank Policy Research Working Paper(5430). Récupéré sur http://papers.ssrn.com/sol3/papers.cfm?abstract_id=1682130

Khan, M. S., \& Senhadji, A. S. (2000). Threshold Effects in the Relationship Between Inflation and Growth. International Monetary Fund, 1-32.

King , R. G., \& Levine , R. (1993). Finance and Growth : Schumpeter Might Be Right. Quarterly Journal of Economics, 108, 717-737.

Kopp, A. (2007). Incidence des investissements routiers sur la productivité macroéconomiqueréevaluation du cas de l'Europe Occidentale. OCDE/CEMT de recherche sur les transports, pp 79-102.

Kremer, S., Bick, A., \& Nautz, D. (2013). Inflation and Growth: New Evidence from a Dynamic Panel Threshold. Empirical Economies, 44(2), 861-878. 
Krugman , P. (1988). Financing vs. forgiving a debt overhang. Journal of Development Economics(3), 253-268.

Krugman, P. (1994). Competitiveness: A Dangerous Obsession. Foreign Affairs.

Lafay, G. (1995). La compétitivité européenne face au durcissement de la concurrence internation. Révue économoique, 679-689.

Latruffe, L. (2010). Compétitivité, productivité et efficacité dans les secteurs agricole et agroalimentaire. OCDE.

Limao, N., \& Venables, A. Y. (1999). Infrastructure, Geographical Disadvantage and Transport Costs. The World Bank.

List, F. (1904). National Systems of Political Economy . New York Longmans Green.

Mehouachi, H. (2019). Indice Global de la Compétitivité Davos 2019. Institut Tunisien de la Compétitivité et des Etudes Quantitatives.

Mody, A., \& Reinfeld, W. (1995). Advanced Infrastructure for Time Management: The Competitiveness Edge in East Asian. The Wold Bank, Washington.

Mulder, N., Vialou, A., Rodriguez, M., \& Castilho, M. (2004). La compétitivité de l'agriculture et des industries agroalimentaires dans leMercosur et l'Union européenne dans une perspective de liberalisation commerciale. Centre d'Etudes Propective et d'Informations Internationales (CEPII).

Munnelle, A. H. (1990a). Why has Productivity Growth Declined? Productivity and Public Investment. New England Economic Review, 3-22.

Pesaran, H. M. (2004). General Diagnostic Tests for Cross Section Dependence in Panels. Cambridge Working Papers in Economics, 1-42.

Pesaran, H. M. (2007). A simple panel unit root test in the presence of cross-section dependence. Journal of Applied Econometrics, 22, 265-312.

Porter, M. (1990). The Competitive Advantage of Nations. The Free Press.

Rousse, E. H. (1992). Les performances extérieures de la France et de l'Allemagne : l'effet de l'investissement sur la compétitivité. Economie et statistique.

Scott, B. (1995). US Competitiveness Concepts, Performance and Impclication. Harvard Business School Press.

Sigue, M. (2018). Incidence des investissements en infrastructures routières sur la compétitivité structurelle de l'économie: le cas du Burkina Faso. Ougadougou: thèse de Doctorat Unique, Université 
Ouaga II.

Sigue, M., \& Barry, S. (2020). The effects of financial development on the external performance of WAEMU countries: an ARDL approach. Research Journal of Finance and Accounting. doi:10.7176/RJFA

Ulman, S. (2013). Corruption and National Competitiveness in Different Stages of Country Development. Procedia Economics and Finance, 6, 150 - 160.

Verner, T. (2015). The Effect of Economic Freedom on National Competitiveness: Causality from a Panel of Countries. Journal of Economics, Business and Management, 150-154.

World Bank. (2020). World Development Indicators . World Bank.

Yahyaoui , A., \& Rahmani, A. (2009). Développement financier et croissance économique : Rôle de la qualité des institutions. Panoeconomicus, 3, 327-357. doi:DOI: 10.2298/PAN0903327Y

Yerbanga, A. (2017). Déterminants des exportations intra-UEMOA du Burkina Faso. Revue d'Economie Théorique et Appliquée, 1-16. 